\title{
Resistance spot welding between aluminum and magnesium with zinc and tin insert
}

\author{
Ning Wang ${ }^{1,}$ a , Ranfeng Qiu ${ }^{1,2,{ }^{*}}$,Dan $\mathrm{Li}^{1}$,Yugang $\mathrm{He}^{1}$ \\ ${ }^{1}$ School of Materials Science and Engineering, Henan University of Science and Technology, \\ Luoyang, 471003, China; \\ ${ }^{2}$ Collaborative Innovation Center of Nonferrous Metals, Henan Province, Luoyang, China; \\ awning0725@sina.com, *quurf1221@163.com
}

\begin{abstract}
Keywords: Resistance spot welding; Aluminum alloy; Magnesium alloy ;Interlayer
Abstract. In this paper, the dissimilar resistance spot welding of A6061 aluminum alloy and AZ31 magnesium alloy sheet is studied, and the middle layer is $\mathrm{Zn}$ and $\mathrm{Sn}$. The results show that the addition of $\mathrm{Zn}$ and $\mathrm{Sn}$ as the intermediate layer can effectively prevent the formation of intermetallic compounds, and can enhance the quality of the joint. It is found that with the increase of welding current, the tensile shear load of the welded joint increases first and then begins to decrease. $\mathrm{Mg}$ - $\mathrm{Al}$ compound formation was not observed at the interface of the joint. The results show that the addition of the middle layer hinders the direct contact between aluminum and magnesium, inhibits the interface reaction and improves the performance of the joint.
\end{abstract}

\section{Introduction}

With the development of industry, there has been a growing interest in using lightweight materials for fabrication of auto-body structures which will contribute to improved fuel efficiency and reduced environmental impacts ${ }^{[1]}$. Aluminum and magnesium have been paid extensive attentions due to their advantages such as low density, high specific strength and high specific stiffness. Therefore, it is necessary to joining aluminum and magnesium because it not only can reduce the structure weigh but also can save materials. In this regard, there has been a large number of studies focus on the joining of dissimilar aluminum and magnesium. However, it is easily create hot crack and void issues when aluminum and magnesium were welded by using traditional fusion welding methods. Resistance spot welding is a solid state joining technique applied for almost all known metals, and one of the oldest electric welding processes in use today. The weld is made by the combination of heat, pressure, and time $^{[2-4]}$. So this method can avoid above issues to a certain extent. Unfortunately, direct joints between aluminum and magnesium suffer from poor strength and ductility. Such poor mechanical properties are a result of development of brittle inter-metallic phase, i.e, $\mathrm{Mg}_{17} \mathrm{Al}_{12}$ and $\mathrm{Al}_{3} \mathrm{Mg}_{2}$ during welding, as already investigated in literature ${ }^{[5-8]}$. Thus, in order to achieve a strong joint during welding, direct contact between aluminum and magnesium should be avoided. This can be achieved by inserting an inter-layer element at the contact area of the two base materials.

In previous researches, zinc and tin all have been used as an insertion between aluminum and magnesium to improve the properties of the joints. However, there have not researches about the combined function of zinc and tin. Therefore, in this paper, zinc and tin was used as inter-layer for dissimilar joining of A6061 to AZ31 by resistance spot welding. Attempts have been made to improve the mechanical properties via optimizing the welding parameters. The micro-structural characteristics and fracture mechanism of the joints are discussed.

\section{Experimental procedures}

In the present study, a $2 \mathrm{~mm}$ thick sheet of $\mathrm{A} 6061 \mathrm{Al}$ alloy and a $1.5 \mathrm{~mm}$ thick sheet of $\mathrm{AZ} 31 \mathrm{Mg}$ alloy were used. The nominal compositions and thermal properties were listed in the table 1 and table 2, respectively. They were welded using the technology of resistance spot welding with both $60 \mu \mathrm{m}$ thick zinc and tin as inter-layer, zinc is adjacent to the $\mathrm{Al}$ side and tin is adjacent to the $\mathrm{Mg}$ side according to 
binary phase diagram. The specimens were $100 \mathrm{~mm}$ long and $30 \mathrm{~mm}$ wide. Fig. 1 shows the schematic diagram of the process and shape of specimen. The welding current was changed every $2.5 \mathrm{kA}$ between 20 and $35 \mathrm{kA}$ at the fixed welding time of $0.4 \mathrm{~s}$ and electrode force $2 \mathrm{kN}$.

Table 1 chemical composition of materials

\begin{tabular}{cccccccccc}
\hline Materials & $\mathrm{Al}$ & $\mathrm{Mg}$ & $\mathrm{Fe}$ & $\mathrm{Mn}$ & $\mathrm{Zn}$ & $\mathrm{Si}$ & $\mathrm{Ti}$ & $\mathrm{Ni}$ & $\mathrm{Ga}$ \\
\hline A6061 & Bal. & 0.95 & 0.33 & 0.04 & 0.014 & 2.1 & 0.022 & 0.014 & 0.013 \\
AZ31 & 2.9 & Bal. & 0.005 & 0.3 & 1.1 & 0.01 & - & 0.005 & - \\
\hline
\end{tabular}

Table 2 Electrical and thermal properties of the materials

\begin{tabular}{ccccc}
\hline Materials & $\begin{array}{c}\text { Melting } \\
\text { point }\left[{ }^{\circ} \mathrm{C}\right]\end{array}$ & $\begin{array}{c}\text { Electrical } \\
\text { resistivity }\left[\times 10^{-8} \Omega \mathrm{m}\right]\end{array}$ & $\begin{array}{c}\text { Thermal } \\
\text { conductivity }\left[\mathrm{Wm}^{-1} \mathrm{~K}^{-1}\right]\end{array}$ & $\begin{array}{c}\text { Linear } \\
\text { expansivity }\left[\times 10^{-6} \mathrm{~K}^{-1}\right]\end{array}$ \\
\hline A6061 & $570-640$ & 2.65 & 247 & 23.8 \\
AZ31 & $566-632$ & 9.2 & 96 & 26.8 \\
Pure Sn & 232 & 0.16 & 60.7 & 23.8 \\
Pure Zn & 419.5 & 5.96 & 113 & 39.7 \\
\hline
\end{tabular}

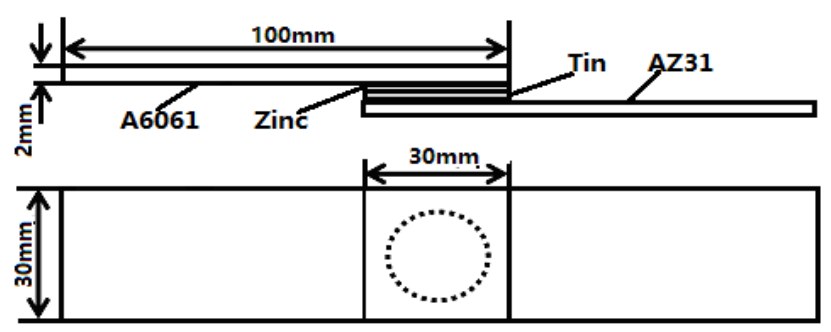

Fig. 1. Tensile shear test specimen

After welding, the specimens were cross-sectioned, ground and polished. the tensile shear tests were performed on AG-1250 kN tensile testing machine under a cross-head velocity of $1.7 \times 10^{-5} \mathrm{~m} / \mathrm{s}$ at room temperature. The microstructure at the welding interface was observed using a scanning electron microscope (SEM) equipped with energy dispersive X-ray analysis (EDS). Element distributions on the fracture surface were determined using electron probe microanalysis (EPMA). The joint tensile load and nugget diameter were determined based on the average value over three measurement per-condition.

\section{Results and discussions}

Fig. 2 shows the effect of welding current on tensile shear load and nugget diameter. As shown in the picture, the nugget diameter increased with the increasing of welding current. In RSW process, heat input increased with the increasing of welding current based on Joule's law, result in increasing nugget diameter. In this study, the nugget diameter is in the range from 7.72 to $10.32 \mathrm{~mm}$ and is in accordance with the relation of $\mathrm{D}>4 \mathrm{t}^{0.5}$ ( $\mathrm{D}$ is nugget diameter, $\mathrm{t}$ is thickness of sheet), it meets the requirements of relevant standards.

The relation between tensile shear load and welding current is non-monotonic. Tensile shear load firstly increased with the increasing of welding current until the maximum tensile shear load was obtained when welding current was $27.5 \mathrm{kA}$, then tensile shear load decreased with the increasing of welding current. As we all know, tensile shear load is proportional to nugget diameter, so tensile shear load increased with the increasing of welding current. However, the indentation of the sheet materials is also proportional to the welding current, so the fracture will produce at the base material which will be discussed in detail later. This also illustrate the reason why tensile shear load decreased with the increasing of welding current after welding current is $27.5 \mathrm{kA}$. The author also found that failure mode is lamellar tearing before welding current is $27.5 \mathrm{kA}$, then the other failure mode is button type tearing. 


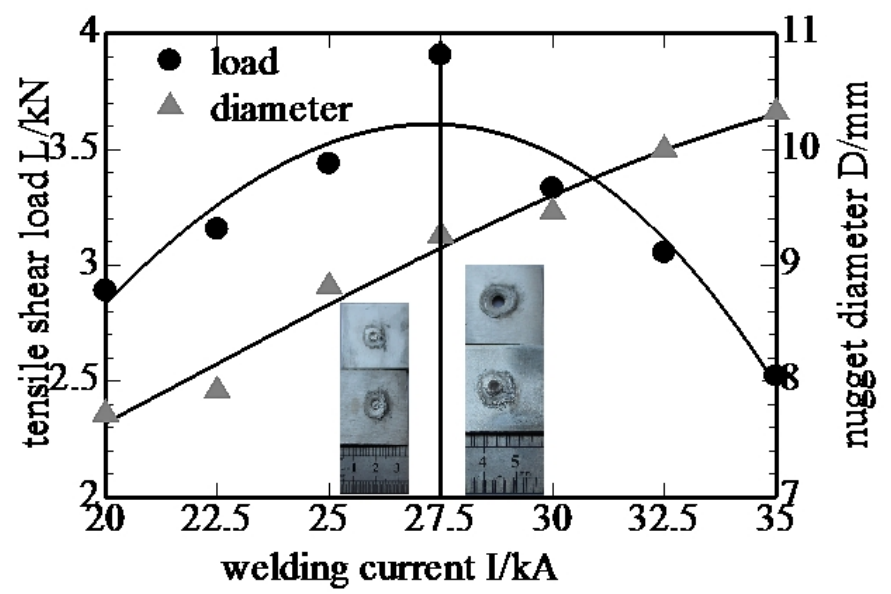

Fig. 2. Effect of welding current on mechanical properties of joint

Fig. 3 shows typical interfacial microstructures of the interface area were observed by scanning electron microscopy (SEM). It can be seen that there are four distinct tissues between $\mathrm{Mg}$ and $\mathrm{Al}$ from the figure. The EDS results are shows in Table 3.

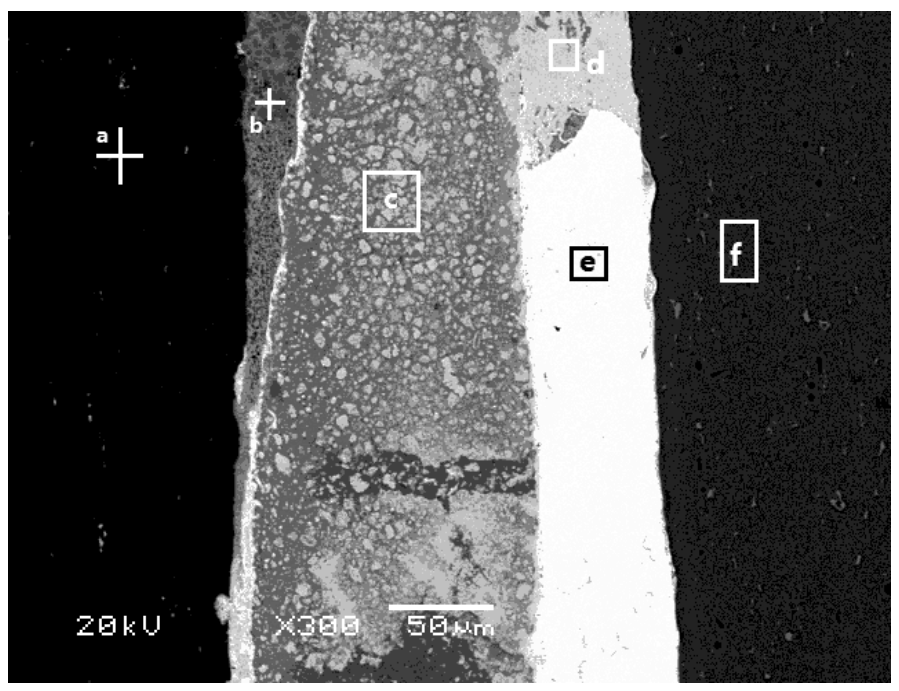

Fig. 3 Electronic scanning electron microscopy (SEM) of the joint

Table 3 EDS analysis results (at.\%) for the highlighted regions

\begin{tabular}{|c|c|c|c|c|c|c|c|}
\hline & & $\mathrm{a}$ & b & $\mathrm{c}$ & d & $\mathrm{e}$ & $\mathrm{f}$ \\
\hline \multirow{4}{*}{$\begin{array}{c}\text { Percentage } \\
\text { composition } \\
\text { [at.\%] }\end{array}$} & $\mathrm{Mg}$ & 96.74 & 64.90 & 44.56 & 25.77 & 01.77 & 02.42 \\
\hline & $\mathrm{Al}$ & 02.36 & 13.08 & 25.43 & 06.31 & 00.00 & 97.15 \\
\hline & $\mathrm{Sn}$ & 00.10 & 00.15 & 00.63 & 00.63 & 00.76 & 00.14 \\
\hline & $\mathrm{Zn}$ & 00.79 & 21.88 & 29.38 & 67.29 & 97.46 & 00.29 \\
\hline
\end{tabular}

As the $\mathrm{Mg}-\mathrm{Zn}$ binary phase diagram, It can be analyzed throughout the organization. $\mathrm{B}$ is a $\mathrm{Mg}-\mathrm{Zn}$ binary compound, and the microstructure of the structure is $\alpha-\mathrm{Mg}$ and $\mathrm{Mg}_{51} \mathrm{Zn}_{20}$. $\mathrm{D}$ is mainly $\mathrm{MgZn}_{2}$ and the structure of $\mathrm{C}$ is the mixture of $\mathrm{B}$ and $\mathrm{D}$ tissue. $\mathrm{A}, \mathrm{F}$ are the base metal $\mathrm{Mg}$ and $\mathrm{Al}$, and $\mathrm{E}$ is the non-melted $\mathrm{Zn}$. 


\section{Conclusions}

This work has been concerned with the dissimilar resistance spot welding of A6061 to AZ31 with $\mathrm{Zn} / \mathrm{Sn}$ interlayer. The following conclusions have been drawn:

1. With the increase of welding current, the nugget diameter of the joint also showed an increasing trend. When the current reached $27.5 \mathrm{KA}$, the increasing trend began to slow down. The shear force increases first and then decreases as the welding current increases.

2. The interlayer inhibits the formation of $\mathrm{Mg}-\mathrm{Al}$ intermetallic compounds.

\section{Acknowledgements}

This work was supported by the Natural Science Foundation of China (U1204520), Henan Province Support Plan of Universities and Colleges Innovation Talents (16HASTIT050), Henan Province International Science and Technology Cooperation Projects ( 162102410023 )

\section{References}

[1] M.W. Andure, S.C. Jirapure, L.P. Dhamande, Advance automobile material for lightweight future - a review, IJCA Proceedings on International Conference on Bench-marks in Engineering Science and Technology 2012 ICBEST 2012, pp. 15-22.

[2] Sun DQ, Lang B, Sun DX, Li JB. Microstructures and mechanical properties of resistance spot welded magnesium alloy joints. Mater Sci Eng A. 460 (2007) 494-498.

[3] Kocabekir B, Kacar R, Gunduz S, Hayat F. An effect of heat input, weld atmosphere and weld cooling conditions on the resistance spot weld ability of 316L austenitic stainless steel, J Mater process technol. 195 (2008) 327-335.

[4] Aslanlar S. The effect of nucleus size on mechanical properties in electrical resistance spot welding of sheets used in automotive industry. Mater. Des. 27 (2006) 125-131.

[5] F. Hayat, The effects of the welding current on heat input, nugget geometry, and the mechanical and fractural properties of resistance spot welding on $\mathrm{Mg} / \mathrm{Al}$ dissimilar materials, Mater. Des.32 (2011) 2476-2484.

[6] V. Firouzdor, S. Kou, Al-to-Mg friction stir welding: effect of material position, travel speed, and rotation speed, Metall. Mater. Trans. A. 41 (2010) 2914-2935.

[7] H.M. Rao, W. Yuan, H. Badarinarayan, Effect of process parameters on mechanical properties of friction stir spot welded magnesium to aluminum alloys, Mater. Des. 66 (2015) 235-245.

[8] Y.S. Sato, S.H.C. Park, M. Michiuchi, H. Kokawa, Constitutional liquation during dissimilar friction stir welding of $\mathrm{Al}$ and $\mathrm{Mg}$ alloys, Scr. Mater. 50 (2004) 1233-1236. 